\title{
Oligophrenin-1 Connects Exocytotic Fusion to Compensatory Endocytosis in Neuroendocrine Cells
}

\author{
Sébastien Houy, ${ }^{1 \star}$ Catherine Estay-Ahumada, ${ }^{1 *}$ Pauline Croisé, ${ }^{1}$ Valérie Calco, ${ }^{1}$ Anne-Marie Haeberlé, ${ }^{1}$ \\ Yannick Bailly, ${ }^{1}$ Pierre Billuart, ${ }^{2}$ Nicolas Vitale, ${ }^{1}$ Marie-France Bader, ${ }^{1}$ Stéphane Ory, ${ }^{1} \dagger$ and Stéphane Gasman ${ }^{1} \dagger$ \\ ${ }^{1}$ Institut des Neurosciences Cellulaires et Intégratives, Centre National de la Recherche Scientifique, UPR 3212, and Université de Strasbourg, 67084 \\ Strasbourg, France, and 2Institut Cochin, Département Génétique et Développement, INSERM U 1016, CNRS UMR 8104, Faculté de Médecine de Paris \\ Descartes, 75014 Paris, France
}

Oligophrenin-1 (OPHN1) is a protein with multiple domains including a Rho family GTPase-activating (Rho-GAP) domain, and a Bin-Amphiphysin-Rvs (BAR) domain. Involved in X-linked intellectual disability, OPHN1 has been reported to control several synaptic functions, including synaptic plasticity, synaptic vesicle trafficking, and endocytosis. In neuroendocrine cells, hormones and neuropeptides stored in large dense core vesicles (secretory granules) are released through calcium-regulated exocytosis, a process that is tightly coupled to compensatory endocytosis, allowing secretory granule recycling. We show here that OPHN1 is expressed and mainly localized at the plasma membrane and in the cytosol in chromaffin cells from adrenal medulla. Using carbon fiber amperometry, we found that exocytosis is impaired at the late stage of membrane fusion in Ophn1 knock-out mice and OPHN1-silenced bovine chromaffin cells. Experiments performed with ectopically expressed OPHN1 mutants indicate that OPHN1 requires its Rho-GAP domain to control fusion pore dynamics. On the other hand, compensatory endocytosis assessed by measuring dopamine- $\beta$-hydroxylase (secretory granule membrane) internalization is severely inhibited in $0 p h n 1$ knock-out chromaffin cells. This inhibitory effect is mimicked by the expression of a truncated OPHN1 mutant lacking the BAR domain, demonstrating that the BAR domain implicates OPHN1 in granule membrane recapture after exocytosis. These findings reveal for the first time that OPHN1 is a bifunctional protein that is able, through distinct mechanisms, to regulate and most likely link exocytosis to compensatory endocytosis in chromaffin cells.

Key words: amperometry; chromaffin cells; compensatory endocytosis; exocytosis; neuroendocrine cells; oligophrenin-1

\section{Introduction}

In neuroendocrine cells, the secretion of hormones and neuropeptides occurs through calcium-regulated exocytosis, a process that involves the docking and fusion of large dense core vesicles (secretory granules) with the plasma membrane. To maintain the specific lipid and protein composition of secretory granules and plasma membranes, and to keep the cell surface constant, exocytosis needs to be rapidly followed by a compensatory endocytosis

Received Sept. 30, 2014; revised June 26, 2015; accepted July 1, 2015.

Author contributions: V.C., Y.B., N.V., S.O., and S.G. designed research; S.H., C.E.-A., P.C., V.C., A.-M.H., and S.O. performed research; P.B. contributed unpublished reagents/analytic tools; S.H., C.E.-A., P.C., V.C., A.-M.H., Y.B., P.B., N.V., M.-F.B., S.O., and S.G. analyzed data; N.V., M.-F.B., S.O., and S.G. wrote the paper.

This work was supported by grants from Agence Nationale de la Recherche (2010-BLANC-1434-03), European Union Grant (Gencodys, FP7 241995), and INSERM to P.B.; from "Ligue Contre le Cancer" (comité Alsace 2012-13) to S.G.; by a fellowship from CONICYT Becas Chile, Programa Formación de Capital Humano Avanzado to C.E.-A; and by a PhD Fellowship from "Région Alsace" and "Ligue Contre le Cancer" to S.H. We thank Plateforme Imagerie In Vitro, Neuropôle de Strasbourg for their participation. We also thank Tam Tahouly and Cathy Royer for their technical assistance in chromaffin cell culture and transmission electron microscopy, respectively. In addition, we thank Dr. Vincent Lelièvre and Adrien Lacaud for sharing with us their expertise on qPCR; and Dr. Antoine Valera for his help on Igor programming for amperometric foot detection and analysis.

*S.H. and C.E.-A. contributed equally to this work.

†S.O. and S.G. contributed equally to this work.

Correspondence should be addressed to either Stéphane Ory or Stéphane Gasman, Institut des Neurosciences Cellulaires et Intégratives (INCI), Centre National de la Recherche Scientifique (CNRS UPR 3212) and Université de Strasbourg, 5 rue Blaise Pascal, 67084 Strasbourg, France, E-mail: ory@inci-cnrs.unistra.fr or gasman@inci-cnrs.unistra.fr.

DOI:10.1523/JNEUROSCI.4048-14.2015

Copyright $\odot 2015$ the authors $\quad 0270-6474 / 15 / 3511045-11 \$ 15.00 / 0$ process. Using neuroendocrine chromaffin cells from the adrenal gland, we have previously shown that, after full fusion exocytosis, secretory granule membrane proteins are sorted and segregated together before being recaptured, suggesting a tight spatial and temporal coupling between exocytosis and compensatory endocytosis (Ceridono et al., 2011; Ory et al., 2013). However, the molecular mechanisms of granule membrane recapture and its coupling with exocytosis remain largely unexplored. Multidomain or scaffold proteins that are able to control and coordinate multiple cellular functions represent potential candidates.

Oligophrenin-1 (OPHN1) is a Rho family GTPase-activating protein (Rho-GAP) that contains, in addition to the catalytic GAP domain, several domains including a N-terminal BinAmphiphysin-Rvs (BAR) domain able to sense membrane curvature, a pleckstrin homology domain and three C-terminal proline-rich domains (Billuart et al., 1998; Fauchereau et al., 2003). In neurons, OPHN1 is expressed both presynaptically and postsynaptically, and its loss of function has been associated with X-linked intellectual disability (Billuart et al., 1998). Postsynaptic OPHN1 seems to be important for dendritic spine morphogenesis and for postsynaptic receptor trafficking (Govek et al., 2004; Khelfaoui et al., 2007; Nadif Kasri et al., 2009; Nakano-Kobayashi et al., 2014). The function of OPHN1 at the presynaptic sites is more puzzling. Short-term plasticity like paired-pulse facilitation is altered in hippocampal neurons from OPHN1 knock-out 
mice, suggesting potential changes in the probability of neurotransmitter release, although the underlying molecular aspects linking OPHN1 to exocytosis remained unexplained (Khelfaoui et al., 2007). Moreover, OPHN1 has been shown to regulate synaptic vesicle recycling both through its interaction with endophilin A1, a BAR domain-containing protein implicated in endocytosis, and the inactivation of the RhoA/Rho-associated kinase (ROCK) signaling pathway (Khelfaoui et al., 2009; Nakano-Kobayashi et al., 2009). In view of its ability to control Rho-GTPase activity, sense membrane curvature, and regulate synaptic vesicle endocytosis, we reasoned that OPHN1 could potentially play a pivotal function in coupling exocytosis to endocytosis in neurosecretory cells.

The aim of the present work was to investigate the functional importance of OPHN1 during regulated exocytosis and compensatory endocytosis in neuroendocrine chromaffin cells. Using carbon fiber amperometry and a dopamine- $\beta$-hydroxylase $(\mathrm{DBH})$ antibody internalization assay on chromaffin cells isolated from OPHN1 knock-out mice, we found that both exocytotic fusion and compensatory endocytosis were compromised. Interestingly, OPHN1 appeared to be implicated in these two functions through distinct domains, relying on its Rho-GAP domain to control fusion pore dynamics and requiring its BAR domain to trigger granule membrane endocytosis.

\section{Materials and Methods}

DNA constructs, animals, cell culture, and transfection. The bidirectional expression vector $\mathrm{pBI}-\mathrm{CMV} 1$ (Clontech) was used to simultaneously express the enhanced green fluorescent protein (EGFP) and the OPHN1 proteins in transfected cells. The human wild-type (WT) OPHN1 and R409L mutant (provided by Dr. P. Billuart, Institut Cochin, Paris, France) were amplified by PCR using $5^{\prime}$-TATACGCGTGCCACCATGGGTCATCCCCCGCT-3' and 5'-CATGCGGCCGCTCAACTTTCATCTCCAGGAAG-3' primers. The first 225 aa were deleted from WT OPHN1 to generate the OPHN1 $\triangle$ BAR mutant using 5'-CGCACGCGTGCCACCATGCAACAGCTCC AACTCAGT- ${ }^{\prime}$ and $5^{\prime}$-CATGCGGCCGCTCAACTTTCATCTCCAGG AAG-3' primers. EGFP was amplified using $5^{\prime}$-TATAGATCTCGCCAC CATGGTGAGCAAGGGCGA-3' and 5'-CGCCTGCAGTTACTTGTAC AGCTCGTCCATGC-3' $3^{\prime}$ primers. PCR products were ligated into pBICMV1 between the MluI and NotI restriction sites in MCS1 (OPHN1), and the PstI and BglII restrictions sites in MCS2 (EGFP).

Nineteen base pair long short hairpin RNA were designed to target the bovine sequence of OPHN1 (GAACCTATCTACCACAGCC). Sense and antisense strands separated by a short spacer were synthesized (Life Technologies), annealed, and cloned between the BglII and HindIII sites in front of the $\mathrm{H} 1$ promoter of a pmCherry vector. A vector control was generated by cloning an unrelated sequence (ATTCTATCACTAGCGTGAC; Randhawa et al., 2004) between BglII and HindIII sites. For rescue experiments, using the QuickChangeII XL Site-Directed Mutagenesis kit (Agilent Technologies), wobble mutations (codon GAA encoding Glu338 to GAG and codon CCT encoding Pro339 to CCC) were introduced into OPHN1, OPHN1 $1_{\mathrm{R} 409 \mathrm{~L}}$, and OPHN1 $1_{\triangle \mathrm{BAR}}$ constructs to make them resistant to OPHN1 short hairpin RNA (shRNA). Forward and reverse primers were, respectively, as follows: 5'-CATGGATGGGAA AGAGCCCATCTACCACAGCCCTA-3' and 5'-TAGGGCTGTGGTA GATGGGCTCTTTCCCATCCATG-3'. All constructs were verified by sequencing.

OPHN1 mice with a C57BL/6N background were described previously (Khelfaoui et al., 2007). All mice were bred, handled, and maintained in agreement with European Council Directive 86/609/EEC and the resulting French regulations. The mice were housed and raised at Chronobiotron UMS 3415.

Mouse chromaffin cells were cultured as described previously (Ory et al., 2013). Briefly, adrenal glands from 8- to 12-week-old males were dissected, and chromaffin cells were purified from papain-digested medulla. Cells were seeded on collagen-coated coverslips and maintained at $37^{\circ} \mathrm{C}, 5 \% \mathrm{CO}_{2}$ for $24-48 \mathrm{~h}$ before the experiments. Bovine chromaffin cells were cultured as described previously (Gasman et al., 1997). Mammalian expression vectors $(3 \mu \mathrm{g})$ were introduced into chromaffin cells $\left(5 \times 10^{6}\right.$ cells) by Nucleofactor systems (Amaxa Biosystems) according to the manufacturer instructions. Cells were seeded on fibronectincoated coverslips and cultured for $48 \mathrm{~h}$ before the experiments.

PC12 cells were cultured as described previously (Gasman et al., 2004). A total of $5 \times 10^{4}$ cells $/ \mathrm{cm}^{2}$ were seeded $24 \mathrm{~h}$ before small interfering RNA (siRNA) transfection according to the manufacturer instructions. Lipofectamine RNAiMax (Invitrogen) and an $80 \mathrm{~nm}$ mix of four siRNAs directed against Ophn1 (On Target Plus Smart Pool siRNA; Dharmacon) were used (5'-UGAGAUUAAUAUUGCGGAA-3'; 5'-GGAAGCUGGUAUAUAGGUU-3'; $5^{\prime}$-CGGAAGGAACAAAUAGGUU-3'; 5' -CAU GCAAGCUUCCGGGACA-3'). Cells were cultured for $48 \mathrm{~h}$ before the experiments, and OPHN1 silencing was estimated and normalized to actin contents by Western blotting.

Real-time quantitative PCR. Total RNA from mouse adrenal medulla and cerebellum were prepared using the GenElute Mammalian total RNA Miniprep Kit (Sigma-Aldrich) and then treated with RNase-free DNaseI (Thermo Scientific). After checking RNA integrity and concentration by spectrophotometry and agarose gel electrophoresis, the template RNA was transcribed into cDNA using the Maxima First Strand cDNA Synthesis Kit for real-time quantitative PCR (Thermo Scientific), according to the manufacturer instructions $(1 \mu \mathrm{g}$ RNA/20 $\mu$ l reverse transcriptase reaction). PCR was performed in 96-well plates using diluted cDNA samples, highly gene-specific primers, and SyberGreen PCR reagents (IQ SYBR Green Supermix; Bio-Rad).

Gene amplification and expression analyses were performed on a MyIQ real-time PCR machine (Bio-Rad) using a three-step procedure $\left(20 \mathrm{~s}\right.$ at $95^{\circ} \mathrm{C} ; 20 \mathrm{~s}$ at $62^{\circ} \mathrm{C} ; 20 \mathrm{~s}$ at $72^{\circ} \mathrm{C}$ ) followed by a melting curve study to ensure the specificity of the amplification process. PCR efficiency was evaluated by standard curves analysis and the glyceraldehyde-3phosphate dehydrogenase (GAPDH) was used as an internal control. Gene expression in two different samples was compared using the comparative threshold cycle (Ct) method (Livak and Schmittgen, 2001). Each reaction was performed in triplicate, and the sample was related to GAPDH. The mean $\triangle \mathrm{Ct}$ (Ct OPHN1 - Ct GAPDH) was calculated for each condition, and expression levels were determined and represented as $2^{-\Delta \mathrm{Ct}}$. Primer sequences used against cDNA of mouse origin $\left(5^{\prime}-\right.$ $3^{\prime}$ ) were as follows: OPHN1_Fw: CAGGGACCGGTGGACTTAAC; OPHN1_Rv: AGTGATGGTTCCAGGTCTTTCA; GAPDH_Fw: GGCCTTCCGTGTTCCTAC; and GAPDH_Rv: TGTCATCATACTTGGCA GGTT.

Antibodies, immunofluorescence, and DBH internalization assay. Polyclonal anti-OPHN1 antibody has been described earlier (Fauchereau et al., 2003). Monoclonal anti SNAP25 was from Millipore Bioscience Research Reagents and rabbit polyclonal anti-DBH was as previously described (Ceridono et al., 2011). The mouse monoclonal anti-RhoA (clone 26C4) was from Santa Cruz Biotechnology.

Chromaffin cells were fixed and stained as previously described (Gasman et al., 1998). Cells were observed with a TCS SP5 confocal microscope (Leica Microsystems) using a $63 \times$ objective (numerical aperture, 1.40). For the plasma membrane labeling, cells were washed twice with PBS and incubated for $30 \mathrm{~min}$ at $4^{\circ} \mathrm{C}$ with $0.25 \mathrm{mg} / \mathrm{ml} \mathrm{EZ-Link} \mathrm{Sulfo-}$ NHS-SS-Biotin (Pierce) in PBS. Cells were washed, fixed, and processed for immunofluorescence. Biotinylated proteins were revealed using Alexa Fluor streptavidin conjugates (Life Technologies).

Anti-DBH antibody internalization assay was performed as previously described (Ceridono et al., 2011; Ory et al., 2013). Briefly, bovine chromaffin cells were washed twice in Locke's solution and further incubated at $37^{\circ} \mathrm{C}$ in Locke's solution (resting) or stimulated with an elevated $\mathrm{K}^{+}$ solution for $10 \mathrm{~min}$. Cells were then placed on ice, washed once in Locke's solution, and incubated for $30 \mathrm{~min}$ at $4^{\circ} \mathrm{C}$ in the presence of polyclonal anti-DBH antibodies. Cells were then washed rapidly with Locke's solution and fixed (stimulated) or further incubated in Locke's solution at $37^{\circ} \mathrm{C}$ for $15 \mathrm{~min}$ (endocytosis) before fixation. Cells were then processed for immunofluorescence. For mouse chromaffin cells, cells were rapidly washed and maintained under resting conditions or stimulated for 10 $\min$ at $37^{\circ} \mathrm{C}$ in Locke $\mathrm{K}^{+}$solution in the presence of anti-DBH anti- 
bodies. Cells were then washed with Locke's solution and fixed or further incubated at $37^{\circ} \mathrm{C}$ for $15 \mathrm{~min}$ before fixation and immunofluorescence experiments. As previously described, the distribution of $\mathrm{DBH}$ containing granules was analyzed using a Euclidean distance map (Ceridono et al., 2011). Briefly, confocal pictures were segmented using ImageJ (http://imagej.nih.gov/ij/) to isolate DBH-positive vesicles and to generate a corresponding region of interest. The cell periphery was outlined using plasma membrane marker staining, and the cell area was transformed into a Euclidean distance map where each pixel has a value of the minimum Euclidean distance from the cell periphery. The relative positions of vesicles were determined according to the mean gray intensity measured in each region of interest once they were transposed onto a Euclidean distance map. Vesicles were considered internalized when the mean gray value was $>10$ for bovine and mice chromaffin cells. For more details, see supplemental Figure 1 in the study by Ceridono et al. (2011).

Western blotting and subcellular fractionation. Western blots were performed by chemiluminescence using the Super Signal West Dura Extended Duration Substrate system (Pierce). Immunoreactive bands were detected using the Chemi-Smart 5000 image acquisition system and were quantified using Bio-1D software (Vilber Lourmat).

Subcellular fractionation was performed as previously described (Vitale et al., 1996). Plasma membrane, cytosol, and chromaffin granule membranes were purified from bovine adrenal medulla. Adrenal medullary glands were homogenized in $0.32 \mathrm{~m}$ sucrose $(10 \mathrm{~mm}$ Tris- $\mathrm{HCl}, \mathrm{pH}$ 7.4) and then centrifuged at $800 \times g$ for $15 \mathrm{~min}$. The supernatant was further centrifuged at $20,000 \times g$ for 20 min to pellet the crude membrane extract, and the $20,000 \times g$ supernatant was centrifuged for $60 \mathrm{~min}$ at $100,000 \times g$ to obtain the cytosol (supernatant). The crude membrane extract was resuspended in $0.32 \mathrm{~m}$ sucrose ( $10 \mathrm{~mm}$ Tris- $\mathrm{HCl}, \mathrm{pH} 7.4)$ and layered on a cushion sucrose density gradient (1-1.6 M sucrose, $10 \mathrm{~mm}$ Tris- $\mathrm{HCl}, \mathrm{pH} 7.4$ ), and centrifuged for $90 \mathrm{~min}$ at $100,000 \times g$ to separate the plasma membrane (upper fraction) from secretory granules (pellet). The plasma membrane and secretory granule fractions were collected and resuspended in TED buffer (20 mM Tris- $\mathrm{HCl}$, pH 8.0, 1 mM EDTA, 1 mм DTT). Secretory granule membranes were recovered by centrifugation for $30 \mathrm{~min}$ at 100,000 g. Protein concentration in each fraction was determined by Bradford assay, and $20 \mu \mathrm{g}$ of protein was resolved by SDS-PAGE, transferred to nitrocellulose, and blotted using anti-SNAP25 (plasma membrane marker), anti-DBH (secretory granule membrane marker), or anti-OPHN1 antibodies.

Amperometry. Chromaffin cells from Ophn1 ${ }^{-l y}$ and Ophn1 ${ }^{+/ y}$ mice or transfected bovine chromaffin cells were washed with Locke's solution and processed for catecholamine release measurements by amperometry. A carbon fiber electrode of $5 \mu \mathrm{m}$ diameter (ALA Scientific) was held at a potential of $+650 \mathrm{mV}$ compared with the reference electrode $(\mathrm{Ag} / \mathrm{AgCl})$ and was approached close to GFP-expressing cells. The secretion of catecholamine was induced by a $10 \mathrm{~s}$ pressure ejection of $100 \mathrm{mM} \mathrm{K}^{+}$solution from a micropipette positioned at $10 \mu \mathrm{m}$ from the cell and recorded over 100 s. Amperometric recordings were performed with an AMU130 amplifier (Radiometer Analytical), sampled at $5 \mathrm{kHz}$, and digitally lowpass filtered at $1 \mathrm{kHz}$. The analysis of amperometric recordings was performed as previously described (Poëa-Guyon et al., 2013) with a macro (obtained from the laboratory of Dr. R. Borges; http://webpages.ull.es/ users/rborges/) written for Igor software (Wavemetrics), allowing automatic spike detection and extraction of spike parameters. The number of amperometric spikes was counted as the total number of spikes with an amplitude of $>5 \mathrm{pA}$ within $100 \mathrm{~s}$. The spike parameter analysis was restricted to spikes with amplitudes of $5 \mathrm{pA}$. The quantal size of individual spikes is measured by calculating the spike area above the baseline (Mosharov and Sulzer, 2005). For a pre-spike foot (PSF) signal, the analysis was restricted to spikes with foot amplitudes of $2 \mathrm{pA}$. The term "PSF amplitude" refers to the maximal amplitude of the foot. The data for amperometric spikes were averaged by individual cell.

Transmission electron microscopy of wild-type and Ophn1 knock-out chromaffin cells in situ and secretory granule density analysis. Ophn1 ${ }^{-1 y}$ and $O p h n 1^{+/ y}$ mice $(n=3$ of each genotype) were anesthetized with a mixture of ketamine $(100 \mathrm{mg} / \mathrm{kg})$ and xylazine $(5 \mathrm{mg} / \mathrm{kg})$, and were transcardially perfused with $0.1 \mathrm{M}$ phosphate buffer, $\mathrm{pH} 7.3$, containing $2 \%$ paraformaldehyde and $2.5 \%$ glutaraldehyde. The 2 -mm-thick slices were cut from the adrenal glands and postfixed in $1 \%$ glutaraldehyde in phosphate buffer overnight at $4^{\circ} \mathrm{C}$. The slices were then immersed for $1 \mathrm{~h}$ in OsO4 $0.5 \%$ in phosphate buffer. The $1 \mathrm{~mm}^{3}$ blocks were cut in the adrenal medulla, dehydrated, and processed classically for embedding in Araldite and ultramicrotomy. Ultrathin sections were counterstained with uranyl acetate and examined with a Hitachi model 7500 Transmission Electron Microscope. Secretory granules were counted in 13 and 36 chromaffin cells, respectively, from $O p h n 1^{-1 y}$ and $O p h n 1^{+/ y}$ mice with a visible nucleus randomly selected in ultrathin sections from several blocks (one section/block) from each mouse.

Catecholamine measurement assay. Adrenal glands from 8- to 12-

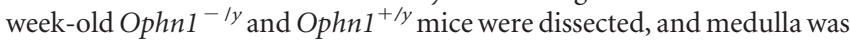
separated from fat and cortex under the microscope. Medulla glands were homogenized in fractionation buffer $(10 \mathrm{~mm}$ Tris, $\mathrm{pH} 7.4,0.32 \mathrm{M}$ sucrose, $4 \mathrm{~mm}$ sodium bisulfite, and protease inhibitor cocktail). Crude tissue extract was cleared after centrifugation for $15 \mathrm{~min}$ at $800 \times g$ to remove unbroken cells and nuclei. Postnuclear supernatant was centrifuged for $1 \mathrm{~h}$ at $100,000 \times g$ to separate secretory granules and membrane-bound vesicles from the cytosol. Catecholamine contents were measured using the 3-CAT Research ELISA Kit (Labor Diagnostika Nord) according to the manufacturer instructions.

Rho GTPase activity assays. Forty-eight hours after siRNA transfection, $\mathrm{PC} 12$ cells were washed twice in Locke's solution at $37^{\circ} \mathrm{C}$, and were either left unstimulated (10 s in Locke's solution) or were stimulated for $10 \mathrm{~s}$ with $59 \mathrm{~mm} \mathrm{~K}^{+}$solution. Cells were quickly lysed at $4^{\circ} \mathrm{C}$, and GTP-bound $\mathrm{Rac} 1$ and Cdc42 were measured according to the manufacturer instructions using the G-LISA Activation Assay Kit (Cytoskeleton). Cdc42 and Rac1 activity was normalized to the total amount of proteins in the cell lysate (adjusted to $1 \mathrm{mg} / \mathrm{ml}$ ). GTP-bound RhoA was measured by pulldown experiments. Cells were lysed for $5 \mathrm{~min}$ on ice $(25 \mathrm{~mm}$ Tris- $\mathrm{HCl}$, pH 7.4, $300 \mathrm{~mm} \mathrm{NaCl}, 2 \%$ IGEPAL CA-630, $10 \mathrm{~mm} \mathrm{MgCl}_{2}$, and protease inhibitor cocktail), scraped, and centrifuged for $2 \mathrm{~min}$ at $20,000 \times g$ at $4^{\circ} \mathrm{C}$. Aliquots were taken from a supernatant of cleared lysates to determine the total amounts of Rho protein and $30 \mu \mathrm{g}$ of glutathione Sepharose beads bound to the recombinant GST fused to Rho Binding Domain (Cytoskeleton) were added to an equal volume of each lysate for $1 \mathrm{~h}$ at $4^{\circ} \mathrm{C}$. Beads were gently spun down and washed four times with $25 \mathrm{~mm}$ Tris $\mathrm{HCl}, 40 \mathrm{~mm} \mathrm{NaCl}, 30 \mathrm{~mm} \mathrm{MgCl}_{2}$, and protease inhibitor cocktail. Precipitated proteins were eluted in Laemmli sample buffer and resolved by SDS-PAGE, and the amounts of Rho proteins estimated by Western blotting using anti-RhoA antibodies. Relative Rho activity was determined by normalizing the amounts of precipitated Rho protein to the total amounts of Rho protein in cell lysate.

Data analysis. Data were analyzed using SigmaPlot version 10 software. Column graphs represent the mean \pm SEM obtained from at least three independent experiments performed on different cell cultures. $n$ represents the number of experiments or the number of cells analyzed, as specified in the figure legends. Box-and-whisker plots represent the first quartile (bottom line), the median (line in the box), the mean (diamondshaped mark), and the third quartile (top line). Whiskers correspond to the 10th (bottom) and 90th (top) percentiles, and dots represent outliers. Statistical significance has been assessed using the Mann-Whitney test when the data did not fulfill the requirements for parametric tests. Data were considered to be significantly different when the $p$ value was $<0.05$.

\section{Results}

\section{Expression and distribution of OPHN1 in adrenal medullary} chromaffin cells

The expression of OPHN1 in adrenal medullary chromaffin cells was first examined by quantitative RT-PCR and Western blot analysis using adrenal medulla tissue and cerebellum tissue as positive controls. Both OPHN1 RNA messenger and protein were detected in the adrenal medulla and cerebellum from Ophn $1^{+/ y}$ mouse (Fig. $1 A, B$ ), but, as expected, we were unable to detect OPHN1 mRNA (data not shown) or protein (Fig. 1B) in tissue from the Ophn1 ${ }^{-1 y}$ mouse. The subcellular distribution of OPHN1 was analyzed by subcellular fractionation of bovine adrenal medulla tissue (Fig. 1C). OPHN1 was detected predomi- 
A

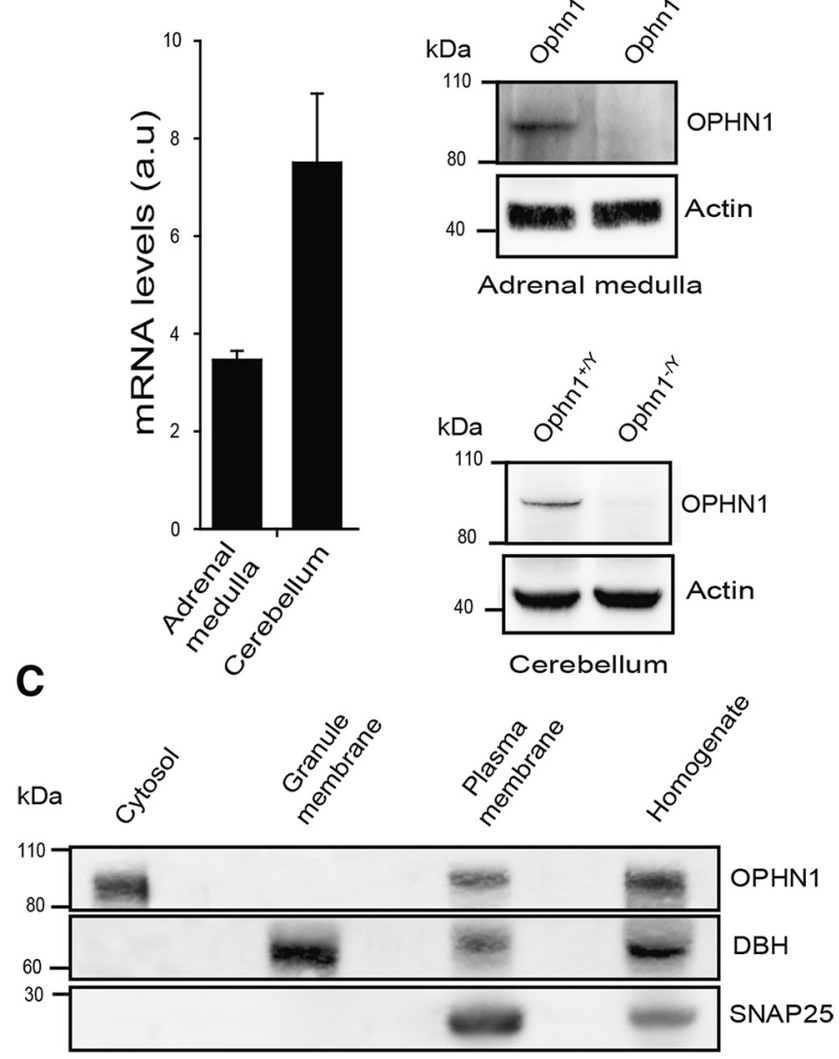

D

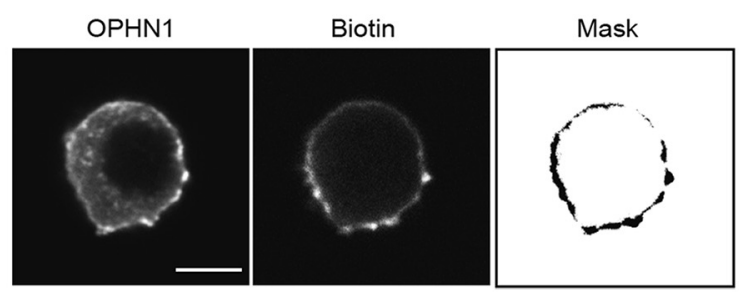

Figure 1. Oligophrenin-1 is expressed at the plasma membrane in adrenal medullary chromaffin cells. $\boldsymbol{A}, \boldsymbol{B}$, Detection of OPHN1 mRNA by quantitative PCR $(\boldsymbol{A})$ and immunodetection of OPHN1 protein by Western blot $(\boldsymbol{B})$ in adrenal medulla and cerebellum from 0 phn $1^{+/ y}$ and Ophn $1^{-1 y}$ mice. Actin is shown as the control of loading. C, Subcellular distribution of OPHN1 in bovine adrenal medulla. Fractions obtained by centrifugation on sucrose gradients were collected, and subjected to gel electrophoresis ( $20 \mu \mathrm{g}$ protein/fraction) and immunodetection using anti-SNAP25 antibodies to detect plasma membranes, anti-DBH antibodies to detect chromaffin granules, and anti-0PHN1 antibodies. $\boldsymbol{D}$, Intracellular localization of ectopically expressed OPHN1 in cultured bovine chromaffin cells. Cells were transfected with the bidirectional expression vector pBI-CMV1 coding simultaneously for EGFP (data not shown) and OPHN1. Plasma membrane was labeled with biotin revealed with Alexa Fluor 633 streptavidin. OPHN1 was detected using anti-OPHN1 antibodies revealed by Alexa Fluor 555-conjugated anti-rabbit antibodies. Mask image highlights the presence of OPHN1 at the plasma membrane. Scale bar, $5 \mu \mathrm{m}$.

nantly in the cytosol and in plasma membrane-containing fractions revealed by the presence of SNAP25, but it was absent from secretory granule-enriched fractions containing DBH. Because we could not detect endogenous OPHN1 by immunofluorescence with the currently available antibodies, we examined the distribution of exogenously expressed untagged OPHN1 in cultured bovine chromaffin cells labeled with biotin to visualize the plasma membrane. As illustrated in Figure 1D, exogenous OPHN1 was mainly present at the cell periphery displaying a staining pattern that colocalized with biotin, confirming the presence of OPHN1 at the plasma membrane in chromaffin cells.
OPHN1 staining was also detected as cytosolic puncta. These puncta did not colocalize with $\mathrm{DBH}$, confirming the absence of OPHN1 from secretory granules (data not shown). However, some of them were labeled with EEA1, a specific marker for early endosomes, suggesting a possible recruitment of OPHN1 to early endosomes (data not shown). Note that the distribution of OPHN1 was not modified in chromaffin cells stimulated with a secretagogue (data not shown).

OPHN1 is involved in exocytosis and fusion pore formation

To address the potential role of OPHN1 in exocytosis, we measured catecholamine release from chromaffin cells lacking OPHN1 expression using carbon fiber amperometry to monitor real-time singlegranule exocytosis (Mosharov and Sulzer, 2005). Figure $2 A$ shows a representative amperometric trace recorded from chromaffin cells cultured from Ophn1 $1^{+/ y}$ and $O p h n 1^{-l y}$ mice. Cells were stimulated with a depolarizing concentration of $\mathrm{K}^{+}$for $10 \mathrm{~s}$, and amperometric spikes were measured over a period of $100 \mathrm{~s}$. As illustrated in Figure $2 B$, the number of amperometric events in response to $\mathrm{K}^{+}$stimulation appeared to be slightly reduced in Ophn1 ${ }^{-l y}$ chromaffin cells compared with wild-type cells, indicating that the absence of OPHN1 to some extent affected the number of exocytotic granule fusion events.

Next, we analyzed the shape of the individual amperometric spikes. Each spike represents a single-granule fusion event with the surface area or quantal size being proportional to the amount of catecholamine released per event, with the half-width reflecting the duration of the exocytotic event and the spike height value reflecting the maximal flux of catecholamine (Fig. 2C). We found that both the quantal size and the spike amplitude were reduced in knock-out cells compared with wild-type cells (Fig. $2 C$ ), suggesting that the absence of OPHN1 might affect either the fusion pore formation/expansion or the granule size and/or catecholamine content. Secretory granule catecholamine content was estimated by measuring the levels of epinephrine, norepinephrine, and dopamine in a granule-enriched subcellular fraction prepared from Ophn1 ${ }^{-l y}$ and $O p h n 1^{+/ y}$ mice adrenal medulla, but no significant differences were observed (Fig. 2D). Secretory granules in adrenal glands from $O p h n 1^{-1 y}$ and $O p h n 1^{+l y}$ mice were also examined by electronic microscopy and morphometric analysis to detect possible morphological changes (Fig. 2E). However, neither the intracellular distribution nor the average diameter of large dense core granules were significantly modified in Ophn1-deficient chromaffin cells. Thus, the absence of OPHN1 did not modify secretory granule biogenesis and catecholamine storage, suggesting that the reduced amplitude and charge of the amperometric spikes observed in Ophn1 knock-out cells is likely to reflect a defect in the exocytotic fusion event.

Amperometric spikes are often preceded by so-called PSF currents that are believed to reflect the slow release of catecholamine through an initial narrow fusion pore before its subsequent rapid expansion that gives rise to the spike (Chow et al., 1992; Bruns and Jahn, 1995; Albillos et al., 1997). We assessed whether OPHN1 is involved in the early fusion pore formation by analyzing the PSF currents in wild-type and Ophn1 knock-out chromaffin cells (Fig. 3). We found that the total PSF charge was largely reduced in cells lacking Ophn1 (Fig. 3B), most likely due to a significant reduction in the maximal foot amplitude (Fig. $3 C$ ), whereas the foot duration remained unchanged (Fig. 3D). PSF amplitude has been correlated to the conductance of the nascent fusion pore (Albillos et al., 1997). Thus, OPHN1 might be implicated in the formation (diameter size) of the initial exocytotic fusion pore.

Altogether, these amperometric results are consistent with a role for OPHN1 in the late stages of large dense core secretory 
A

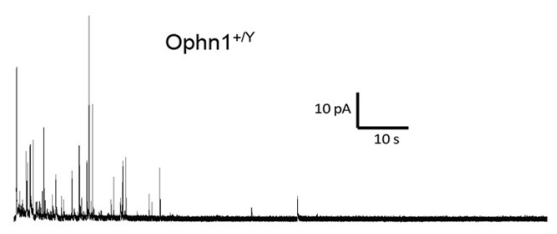

Ophn1-r

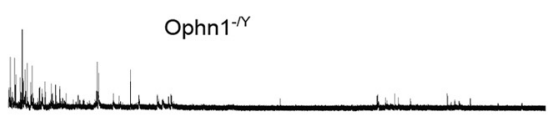

C

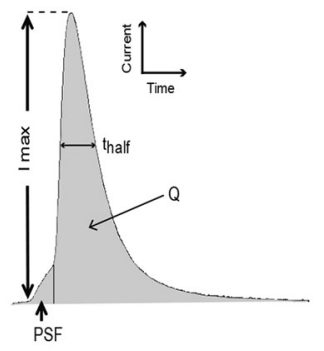

D

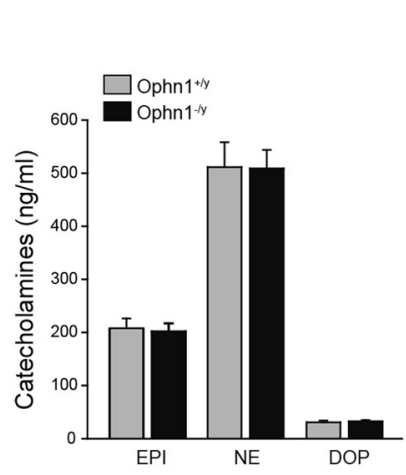



E



B
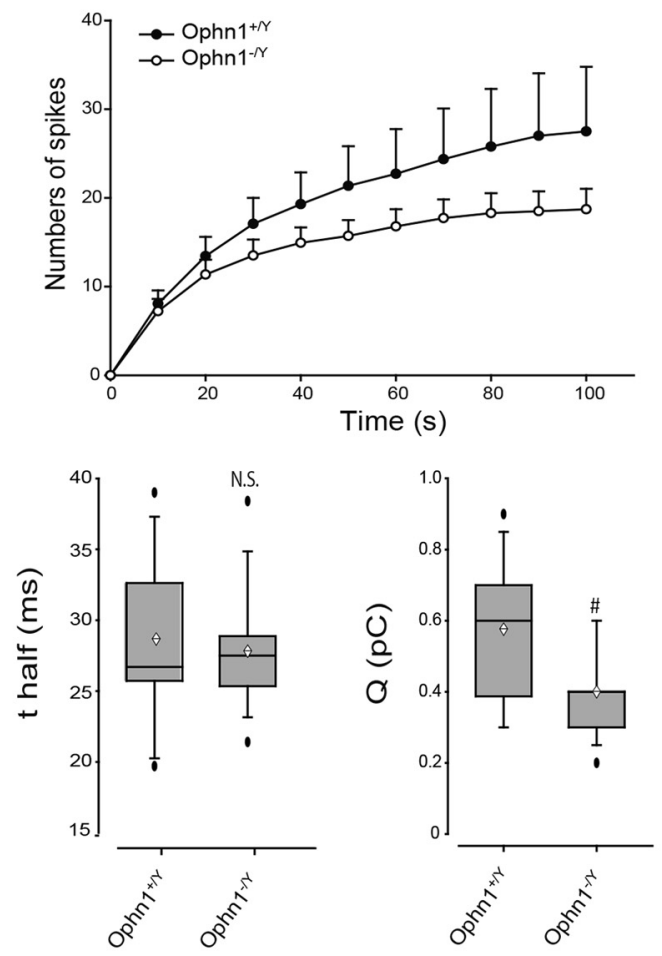

Figure 2. Amperometric analysis of catecholamine secretion from Ophn1 knock-out mice chromaffin cells. $A$, Representative amperometric recordings obtained from cultured chromaffin cells from Ophn $1^{+/ y}$ and Ophn $1^{-/ y}$ mice. Cells were stimulated for $10 \mathrm{~s}$ by a local application of $100 \mathrm{~mm} \mathrm{~K}{ }^{+}$. B, Cumulative number of spikes during 100 s of recording of Ophn $1^{+/ y}$ or 0 phn $1^{-/ y}$ cells. Data are reported as the mean \pm SEM. $n=18$ cells. $C$, Scheme of an amperometric spike describing the following different parameters analyzed: quantal size or charge $(Q)$, half-width $\left(t_{1 / 2}\right)$, spike amplitude $\left(I_{\max }\right)$, and PSF signal. Box-and-whisker plot for spike amplitude, half-width, and spike charge in Ophn ${ }^{+/ y}$ or Ophn ${ }^{-/ y}$ cells are shown. Black circles and white diamonds represent outlier observations and mean values, respectively. Statistical significance for median values was determined by a Mann-Whitney nonparametric median analysis. $n=18$ cells; \#p $<0.01$. n.s., Not significant. D, Catecholamine content of a secretory granule-enriched subcellular fraction prepared from the adrenal medulla of Ophn ${ }^{+/ y}$ and 0 phn $1^{-/ y}$ mice was analyzed for total levels of epinephrine (EPI), norepinephrine (NE), and dopamine (DOP) by ELISA (3CAT Assay, Labor Diagnostika Nord). $\boldsymbol{E}$, Representative transmission electron micrographs of adrenal medulla slices from Ophn $1^{+/ y}$ or Ophn $1^{-/ y}$ mice. Average granule surface area and secretory granule density per square micrometer were measured $(n=60,610$ granules, 78 slices, 3 mice for 0 PHN $1+/ y ; n=66434$ granules, 76 slices, 3 mice for OPHN1 ${ }^{-1 y}$ ).

granule exocytosis, possibly controlling the size of the nascent fusion pore and/or its enlargement to full fusion.

\section{OPHN1 functions as RhoA-GTPase-activating protein to regulate fusion pore formation}

In addition to its catalytic Rho-GAP domain, OPHN1 contains a $\mathrm{N}$-terminal BAR domain known to sense membrane curvature (Daumke et al., 2014). To determine whether OPHN1 requires its Rho-GAP activity or its BAR domain to function in exocytosis, we transfected cultured bovine chromaffin cells with a bidirec- tional expression vector, allowing the constitutive and simultaneous expression of EGFP and wild-type OPHN1, the GAP-dead mutant OPHN1 $_{\text {R409L }}$ (Nakano-Kobayashi et al., 2009), or the BAR domain lacking mutant OPHN1 $1_{\triangle \mathrm{BAR}}$. Bovine chromaffin cells were chosen for these experiments because we failed to transfect mice chromaffin cells. The expression level and distribution of OPHN1 mutants in chromaffin cells are shown in Figure 4A. The two OPHN1 mutants displayed an intracellular localization that was similar to that observed for wild-type OPHN1 with a predominant distribution in the cytosol and at the plasma membrane. 
A
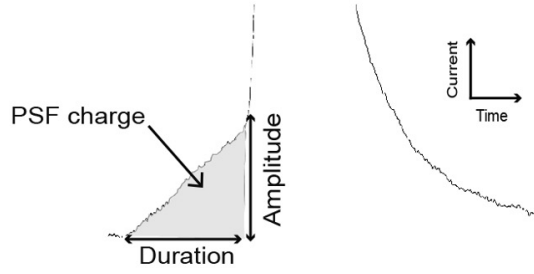

B

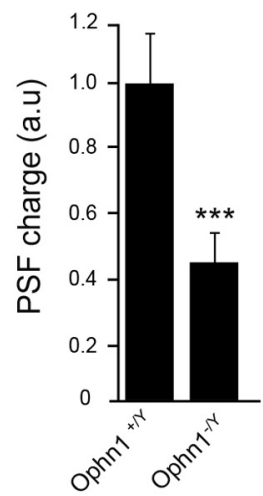

C



D

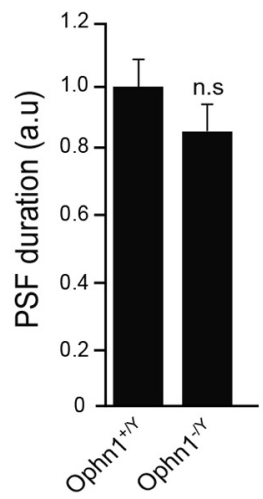

Figure 3. Ophn1 knock-out reduces the charge and amplitude of the pre-spike foot signal. Cultured chromaffin cells from 0 phn $1^{+/ y}$ and $0 p h n 1^{-/ y}$ mice were stimulated by the local application of $100 \mathrm{~mm} \mathrm{~K}^{+}$over $10 \mathrm{~s}$, and secretion was monitored by amperometry. PSF currents recorded from Ophn ${ }^{-/ y}$ chromaffin cells ( $n=14$ cells, 81 PSF currents) were compared with those from Ophn $1^{+/ y}$ cells ( $n=14$ cells, 122 PSF currents). $\boldsymbol{A}$, Scheme of an amperometric PSF describing the following analyzed parameters: amplitude, charge, and duration. $\boldsymbol{B}$, PSF charge average values. C, PSF amplitude average values. D, PSF duration average values. Data are normalized as percentages of the mean value calculated in 0 phn $1^{+/ y}$ cells and are reported as the mean \pm SEM. ${ }^{* * *} p<0.001$. n.S., Not significant (Mann-Whitney test).

A
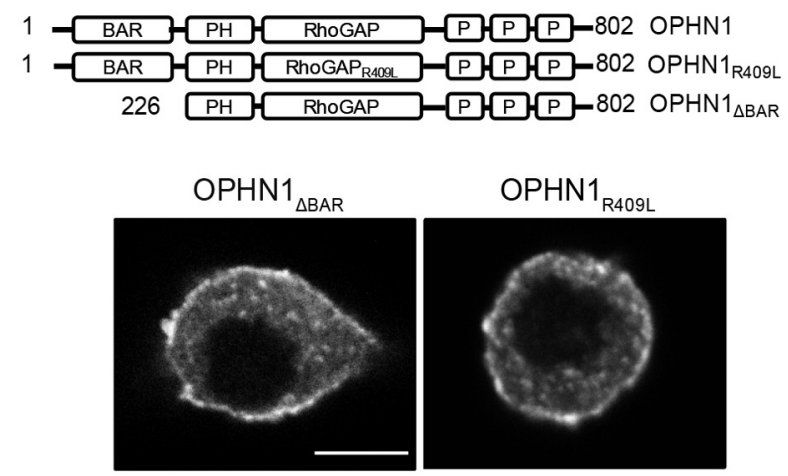

B

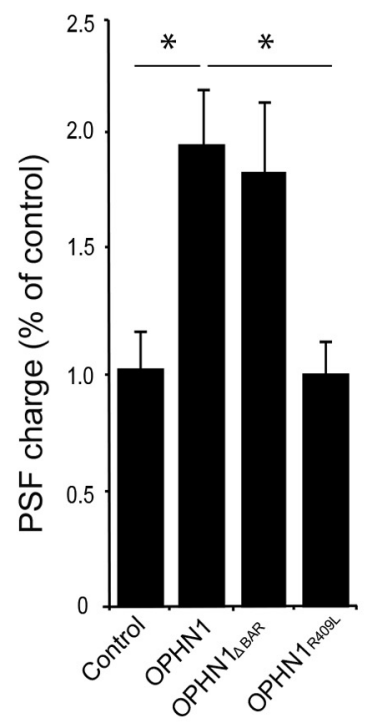

$\mathrm{OPHN1}_{\mathrm{R} 409 \mathrm{~L}}$

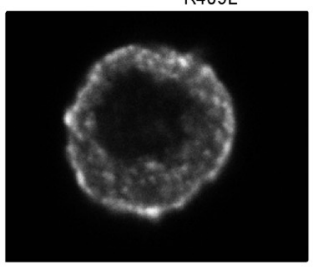

C

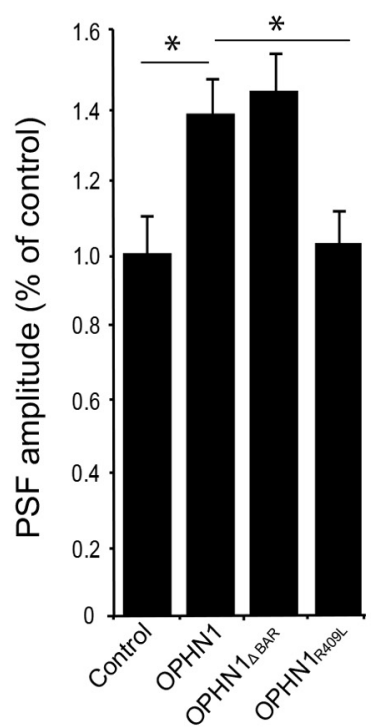

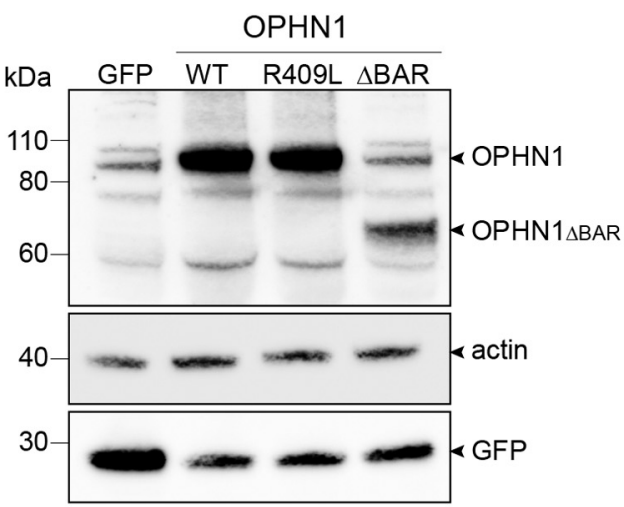

D



Figure 4. OPHN1 overexpression stimulates fusion pore formation. $\boldsymbol{A}$, Schematic representation of OPHN1 and the two constructs used in this study depicting the position of the various functional domains. PH, pleckstrin homology domain; $P$, prolin-rich domain. Bovine chromaffin cells were transfected with a bidirectional expression vector coding simultaneously for EGFP and the indicated OPHN1 constructs. The level of exogenous OPHN1 WT, OPHN1 ${ }_{\triangle B A R}$, and OPHN1 $1_{\text {R409L }}$ expression is analyzed by Western blotting using antibodies against 0 PHN1, EGFP, and actin. The confocal images show the localization of exogenously expressed OPHN1 ${ }_{\triangle B A R}$ and $0 P H N 1_{R 409 L}$ mutants detected by anti-0PHN1 antibodies revealed by Alexa Fluor 555 -conjugated anti-rabbit antibodies. Scale bars,


percentages of control values (considered as $100 \%$ ) and are reported as the mean \pm SEM; control, $n=13$ cells, 51 PSF currents; 0 PHN1, $n=16$ cells, 140 PSF currents; 0 PHN1 R409L, $n=22$ cells,

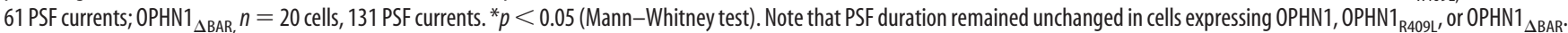


Table 1. Table summarizing the amperometric parameters of the exocytotic events recorded from bovine chromaffin cells expressing the indicated OPHN1 proteins

\begin{tabular}{lclll}
\hline $\begin{array}{l}\text { Amperometric } \\
\text { parameters }\end{array}$ & Control & OPHN1 & OPHN1 $_{\triangle \text { BAR }}$ & OPHN1 $_{\text {R409L L }}$ \\
\hline Events per cell $(n)$ & $22.8 \pm 7.5$ & $53.9 \pm 10.5^{*}$ & $35.2 \pm 9.4$ & $20.7 \pm 2.8 \#$ \\
Spikes analyzed $(n)$ & 191 & 477 & 406 & 307 \\
$Q(\mathrm{pC})$ & $1.5 \pm 0.2$ & $1.1 \pm 0.1$ & $1.3 \pm 0.2$ & $1.2 \pm 0.1$ \\
$t_{1 / 2}(\mathrm{~ms})$ & $46.7 \pm 2.4$ & $42.1 \pm 1.5$ & $43.3 \pm 1.9$ & $45.3 \pm 2.2$ \\
$I_{\text {max }}(\mathrm{pA})$ & $25.9 \pm 2.7$ & $24.7 \pm 2.1$ & $27.2 \pm 3.3$ & $24.3 \pm 2.0$ \\
Cells $(n)$ & 13 & 16 & 20 & 22 \\
\hline
\end{tabular}

Values are given as the mean $\pm S E M$, unless otherwise indicated. $Q$, quantal size or charge; $t_{1 / 2}$, half-width; $I_{\max }$, spike amplitude.

${ }^{*} p<0.01$ compared with control.

$\# p<0.01$ compared with OPHN1.
A

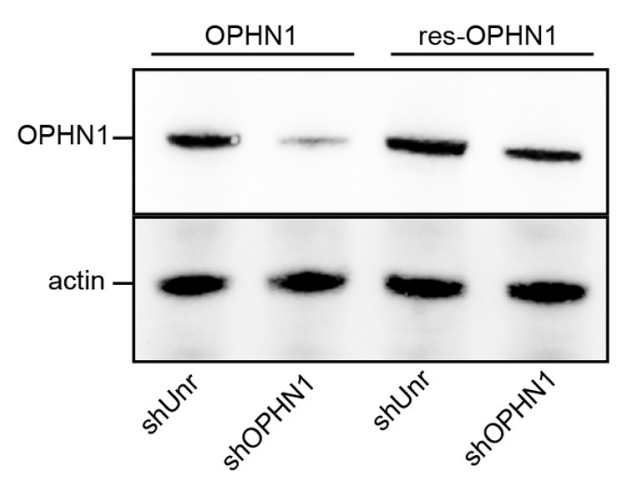

C

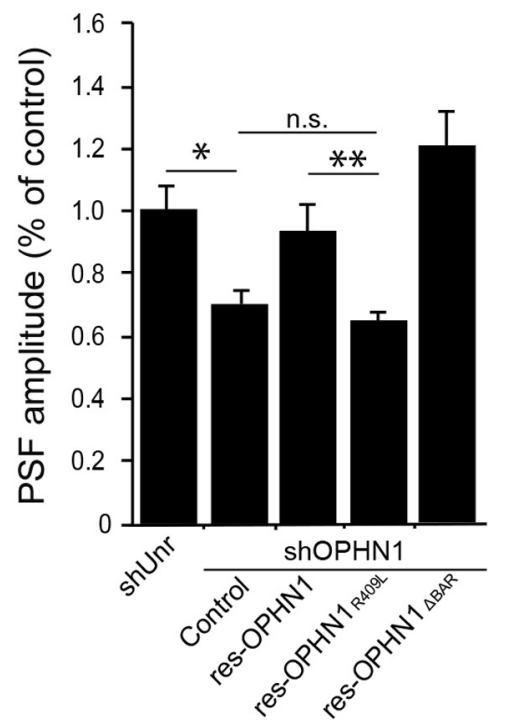

B

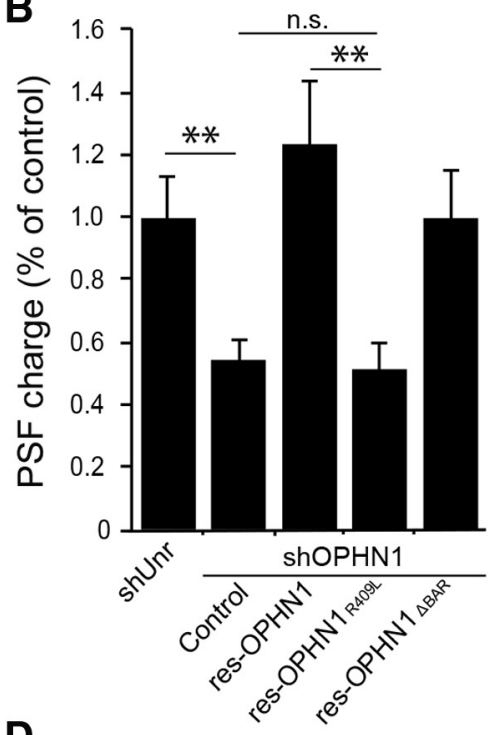

D

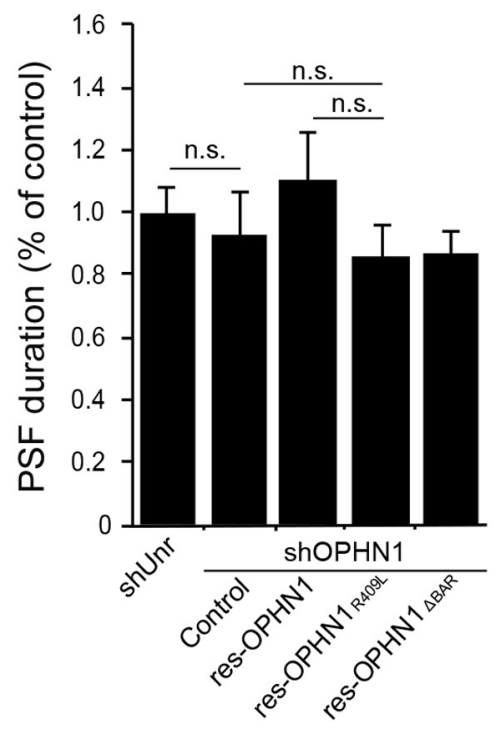

Figure 5. OPHN1 requires its Rho-GAP domain to control fusion pore formation. $\boldsymbol{A}$, The wobble mutations of OPHN1 CDNA confer resistance to shRNA degradation. Constructs coding for unrelated shRNA (shUnr) or OPHN1 shRNA (shOPHN1) were cotransfected in PC12 cells with vector coding either for OPHN1 or for res-OPHN1. Cells were lysed $48 \mathrm{~h}$ after transfection and processed for Western blot analysis using antibodies against OPHN1 and actin. $\boldsymbol{B}-\boldsymbol{D}$, Analysis of PSF charge, amplitude, and duration obtained from bovine chromaffin cells coexpressing shOPHN1 with EGFP alone (control), res-OPHN1, res-OPHN1 $1_{R 409 L}, 0$ res-OPHN1 $1_{\triangle B A R}$. Data are normalized as percentages of control values obtained from chromaffin cells coexpressing EGFP and shUnr, and are reported as the mean \pm SEM; shUnr, $n=30$ cells, 72 PSF currents; shOPHN1/EGFP, $n=36$ cells, 59 PSF currents; sh0PHN1/resOPHN1, $n=24$ cells, 52 PSF currents; sh0PHN1/res-0PHN ${ }_{\text {R409L, }}, n=22$ cells, 53 PSF currents; sh0PHN1/res-0PHN ${ }_{\Delta \text { BAR, }^{\prime}} n=36$ cells, 87 PSF currents. ${ }^{*} p<0.05 ;{ }^{* * *} p<0.001$. n.s., Not significant (Mann-Whitney test).
Cells expressing OPHN1, OPHN1 $1_{\mathrm{R} 409 \mathrm{~L}}$, or OPHN1 $1_{\triangle \mathrm{BAR}}$ were stimulated with high $\mathrm{K}^{+}$and analyzed for catecholamine release by amperometry. Compared with control cells expressing EGFP alone, the overexpression of wild-type OPHN1 increased the number of amperometric events recorded during $100 \mathrm{~s}$ but without significantly modifying any of the spike parameters (Table 1) OPHN1 $1_{\triangle \mathrm{BAR}}$, albeit less effective, enhanced the number of spikes perr without modifying their shape (Table 1). In contrast, the expression of OPHN $1_{\mathrm{R} 409 \mathrm{~L}}$ affected neither the number nor the parameters of the amperometric events compared with control ells (Table 1). When PSF currents were analyzed in cells expressing the OPHN1 proteins, OPHN1 and OPHN1 $1_{\triangle \mathrm{BAR}}$ were found to increase the PSF charge and amplitude without affecting PSF duration, whereas the GAP-dead OPHN1 $1_{\mathrm{R} 409 \mathrm{~L}}$ mutant was without effect (Fig. 4B,C). These data suggest that OPHN1 requires its Rho-GAP activity but not its BAR domain to modify PSF currents. To strengthen this observation, we have tested the effect of OPHN1 mutant expression on PSF currents in bovine chromaffin cells with OPHN1 expression reduced by shRNA. The rescue OPHN1 (res-OPHN1) constructs used for these ex-

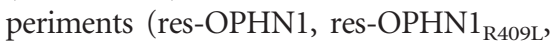
and res-OPHN1 $\left.1_{\triangle \mathrm{BAR}}\right)$ were generated by introducing two mutations on wobble bases, thus conferring resistance to shRNA degradation (Fig. 5A). shRNA-induced reduction of OPHN1 expression did not modify the shape of the amperometric spikes in $\mathrm{K}^{+}$stimulated cells (data not shown), perhaps due to the presence of residual OPHN1, but strongly reduced the charge and amplitude of the PSF currents without affecting the duration (Fig. $5 B-D$ ). Expressing res-OPHN1 or res-OPHN1 $1_{\triangle B A R}$ in cells knocked down for OPHN1 restored PSF charge and amplitude, whereas res- $\mathrm{OPHN} 1_{\mathrm{R} 409 \mathrm{~L}}$ did not (Fig. $5 B, C$ ), confirming that OPHN1 plays a role in PSF currents through its Rho-GAP domain, but not through its BAR domain. In other words, the function of OPHN1 in fusion pore formation implies at some stage the inactivation of a member of the Rho GTPase family.

In vitro GAP assays indicated that OPHN1 is able to inactivate Cdc42, Rac1, and RhoA (Billuart et al., 1998). To identify the Rho GTPase that might be a target for OPHN1 in the exocytotic machinery, we knocked down endogenous OPHN1 in PC12 cells using a siRNA strategy, and measured the level of activated Racl, Cdc42, and RhoA in cells stimulated for $10 \mathrm{~s}$ with elevated potassium levels. We have chosen PC12 cells for these experiments because $80-90 \%$ of the PC12 cell population is efficiently transfected with siRNAs, whereas chromaffin cells in primary culture are resistant to siRNA transfection and efficiently express shRNA in only $10-20 \%$ of the cell population. 
A

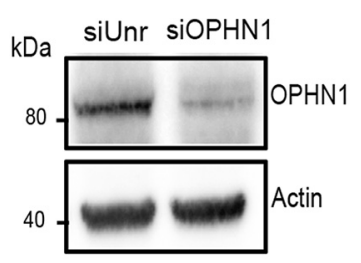

B

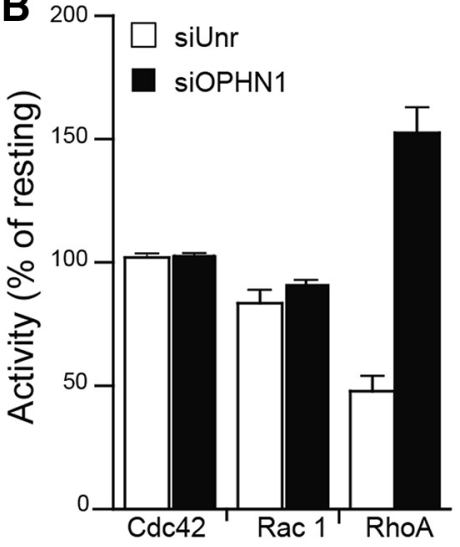

Figure 6. Reduction of the endogenous OPHN1 level affects the RhoA activation/inactivation cycle in secretagogue-stimulated PC12 cells. $A$, Efficiency of the OPHN1 siRNA. PC12 cells transfected with unrelated (siUnR) or OPHN1 siRNA were lysed $48 \mathrm{~h}$ after transfection and processed for Western blot analysis using antibodies against OPHN1 and actin. $\boldsymbol{B}$, Effect of OPHN1 siRNA on the level of GTP-loaded Cdc42, Rac1, or RhoA in resting and stimulated PC12 cells. $P C 12$ cells transfected with siUnr or OPHN1 siRNA were maintained in resting condition in Locke's solution or were stimulated for $10 \mathrm{~s}$ with $59 \mathrm{~mm} \mathrm{~K}^{+}$. Cells were then immediately lysed, and the lysates were used for quantification of the level of GTP-loaded Cdc42 and Rac1 by colorimetric-based ELISA assay or by affinity precipitation of GTP-loaded RhoA. RhoA-GTP that was pulled down was detected by immunoblotting using anti-RhoA antibodies and the level of GTP-loaded RhoA quantified by scanning densitometry analysis. Results are normalized as the percentages of the values obtained in resting cells and are reported as the mean \pm SEM $(n=$ 3). OPHN1 siRNA did not modify the GTP-loaded RhoA/Cdc42/Rac1 level in resting cells.

Western blot analysis confirmed that PC12 cells transfected with OPHN1 siRNA consistently exhibited a significant reduction $(76 \pm 5 \%)$ in the level of endogenous OPHN1 expression (Fig. $6 A$ ). In resting PC12 cells, expressing unrelated siRNA (siUnr) or knocking down OPHN1 expression did not significantly modify the steady-state level of GTP-loaded Rac1, Cdc42, and RhoA (data not shown). A $10 \mathrm{~s}$ stimulation of control PC12 cells (expressing an unrelated siRNA) with a depolarizing concentration of $\mathrm{K}^{+}$did not significantly affect the level of GTP-loaded Cdc42 or Racl but inhibited by $>50 \%$ the level of GTP-loaded RhoA (Fig. 6B). Interestingly, the reduction of endogenous OPHN1 strongly increased the level of GTP-loaded RhoA in $\mathrm{K}^{+}$stimulated PC12 cells, whereas it did not change the level of GTPloaded Cdc42 or GTP-loaded Rac1, suggesting that the activation/inactivation cycle of RhoA was significantly affected in $\mathrm{K}^{+}$-stimulated cells exhibiting a reduced level of OPHN1 (Fig. $6 B$ ). Thus, OPHN1 appears to be linked to RhoA in the course of calcium-regulated exocytosis.

\section{OPHN1 is implicated in secretory membrane compensatory endocytosis}

Since OPHN1 has been described to regulate synaptic vesicle recycling in neurons (Khelfaoui et al., 2009; Nakano-Kobayashi et al., 2009), it is tempting to imagine that it might also be able to play a role in compensatory endocytosis of secretory granules in neuroendocrine cells. We tested this hypothesis by performing an anti-DBH antibody internalization assay in chromaffin cells from knock-out Ophn1 ${ }^{-l y}$ mice. DBH antibody internalization takes advantage of the transient accessibility of DBH (an intraluminal membrane-associated granule protein) to the extracellular space during exocytotic granule membrane fusion. Granule membrane recapture and compensatory endocytosis can be specifically measured and quantified by following the internalization of the antiDBH antibodies after exocytosis (Ceridono et al., 2011; Ory et al.,

2013). DBH internalization was severely inhibited in the absence of OPHN1 (Fig. $7 A$ ). We found that $15.9 \pm 3.8 \%$ of the total DBH was internalized in Ophn1 $1^{-1 y}$ cells compared with $59.2 \pm 3.3 \%$ in Ophn1 $1^{+/ y}$ chromaffin cells (Fig. $7 B$ ), revealing that OPHN1 plays an essential function in the pathway mediating compensatory endocytosis of the secretory granule membrane.

To probe the importance of the BAR domain versus the GAP domain in the function of OPHN1 during compensatory endocytosis, we transfected cultured bovine chromaffin cells to express EGFP and wild-type OPHN1, OPHN1 $1_{\mathrm{R} 409 \mathrm{~L}}$, or OPHN $1_{\triangle \mathrm{BAR}}$, and examined the effect of these proteins on DBH internalization following $\mathrm{K}^{+}$-evoked exocytosis. As illustrated in Figure 7, $C$ and $D, D B H$ internalization remained unchanged in cells expressing wild-type OPHN1 compared with control cells transfected with the empty vector (control). DBH internalization was also unaffected in cells expressing the GAP-deficient $\mathrm{OPHN1}_{\mathrm{R} 409 \mathrm{~L}}$ mutant, suggesting that OPHN1 is not linked to Rho GTPases in the machinery underlying compensatory endocytosis. In contrast, the expression of OPHN $1_{\triangle \mathrm{BAR}}$ severely reduced the amount of internalized $\mathrm{DBH}$, which is in line with the idea that the BAR domain of OPHN1 is critical for secretory granule membrane retrieval after exocytosis. Similar results were obtained in bovine chromaffin cells with OPHN1 expression reduced by shRNA, and the expression of res-OPHN1 $1_{\mathrm{WT}}$ or res$\mathrm{OPHN1}_{\mathrm{R} 409 \mathrm{~L}}$, but not res-OPHN1 $1_{\triangle \mathrm{BAR}}$, significantly rescued endocytotic activity, confirming that the BAR domain of OPHN1 plays an important role in endocytosis (data not shown).

\section{Discussion}

Studies from many laboratories have revealed that Rho GTPases are closely connected to vesicular trafficking at the cell surface (for review, see Ory and Gasman, 2011; de Curtis and Meldolesi, 2012; Croisé et al., 2014). In neuroendocrine cells, we and others have described that Rho GTPases control calcium-regulated secretion at diverse crucial stages, including cortical cytoskeletal remodeling and the production of fusogenic lipids at the exocytotic sites (Gasman et al., 1999; Frantz et al., 2002; Li et al., 2003; Gasman et al., 2004; Momboisse et al., 2009a; Wang and Thurmond, 2010; Bretou et al., 2014). Rho GTPases are molecular switches that undergo a tightly regulated activation/inactivation cycle. Activation is under the control of guanine nucleotide exchange factors (GEFs), and inactivation requires GAPs. Rho GEFs have been described in the exocytotic pathway (Malacombe et al., 2006; Momboisse et al., 2009b). In contrast, and despite their potential importance as off signals capable of terminating hormone release, the GAPs triggering Rho GTPase inactivation have so far not been identified. There is only one report proposing that the neuronal Rho GAP nadrin regulates calcium-regulated exocytosis in PC12 cells (Harada et al., 2000), although the physiological relevance of this observation is questioned by the fact that nadrin is not expressed in the adrenal medulla (Harada et al., 2000). In the present study, we report that the Rho-GAP OPHN1 has a pivotal function in chromaffin cells at the crossroads of secretory granule exocytosis and in subsequent compensatory endocytosis. So far, OPHN1 has essentially been described in neuronal dendritic spine development, plasticity, and synaptic vesicle recycling (Govek et al., 2004; Khelfaoui et al., 2007; Khelfaoui et al., 2009; Nadif Kasri et al., 2009; Nakano-Kobayashi et al., 2009). To our knowledge, this is the first report that identifies OPHN1 in the molecular machinery for neuroendocrine secretion. 


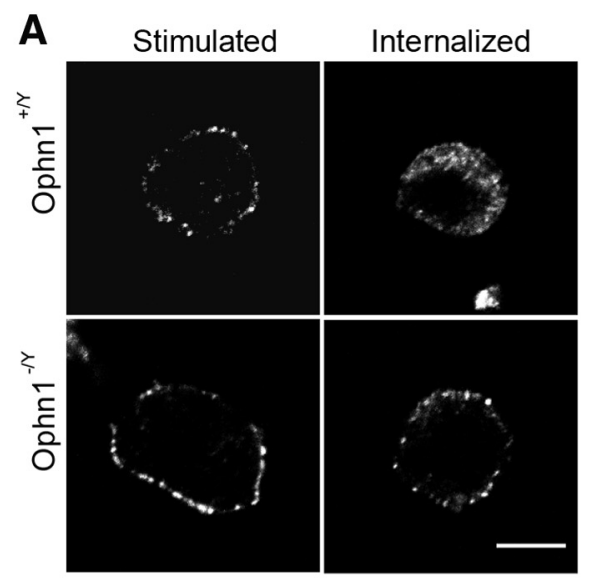

c
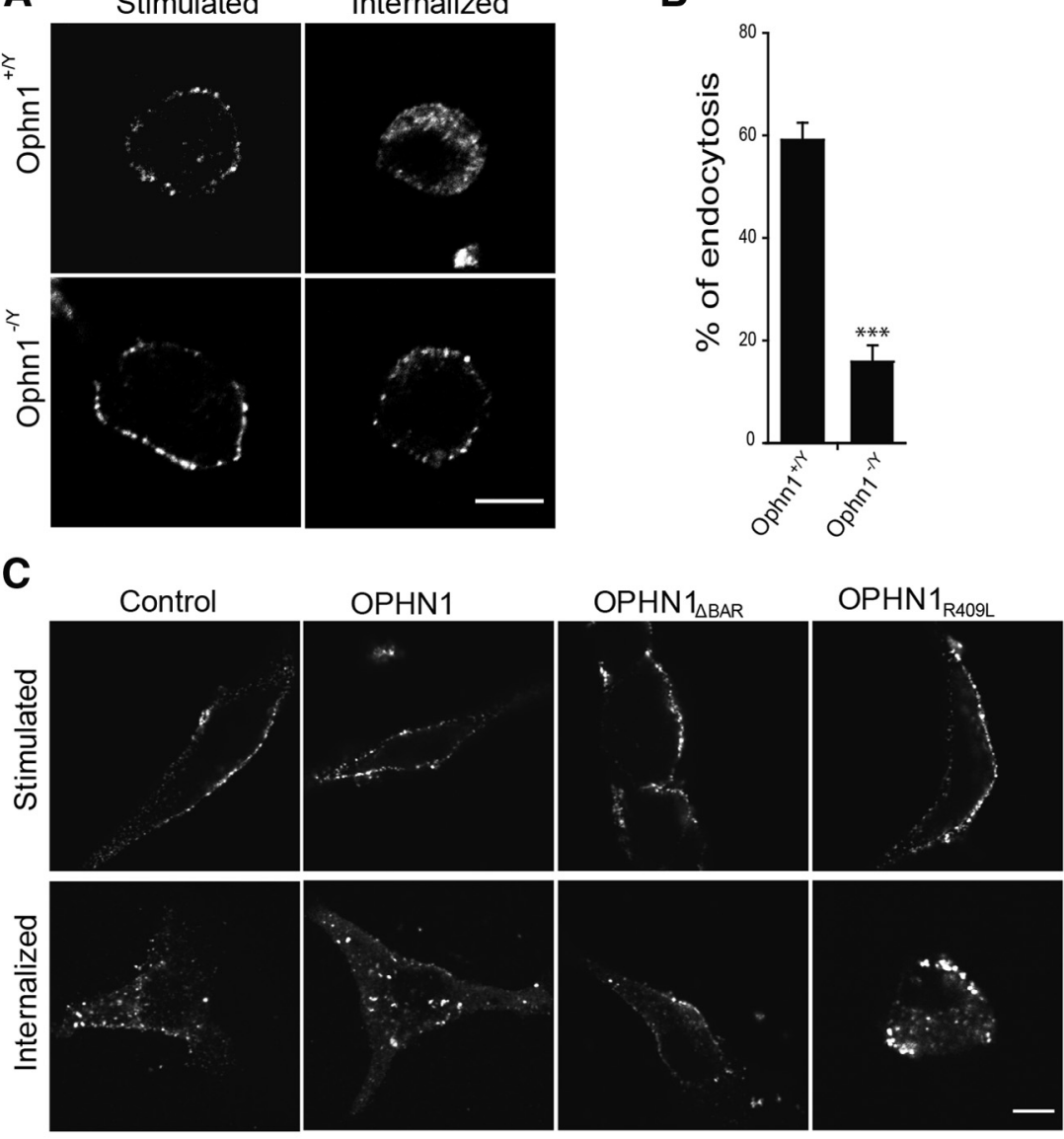

D



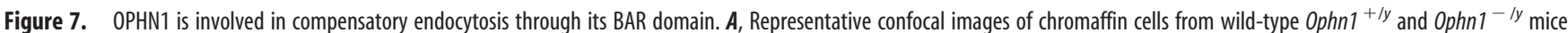
subjected to an anti-DBH antibody internalization assay. (ells were stimulated with $59 \mathrm{~mm} \mathrm{~K}^{+}$for 10 min in the presence of anti-DBH antibodies and fixed (stimulated) or maintained for an additional 15 min period in Locke's solution without antibodies to allow DBH/anti-DBH uptake (internalized). Cells were fixed, permeabilized, and processed for anti-DBH detection using secondary antibodies coupled to Alexa Fluor 555. Scale bar, $5 \mu \mathrm{m}$. B, Analysis of DBH-positive vesicle endocytosis using a Euclidean distance map. DBH uptake was reduced by $75 \%$ in the absence of 0 PHN1 $\left(0 p h n 1^{-/ y}\right) .{ }^{* * *} p<0.001$ (Mann-Whitney test). C, D, OPHN1 requires its BAR domain to regulate compensatory endocytosis. A anti-DBH antibody internalization assay was performed in bovine chromaffin cells expressing EGFP alone, or EGFP together with OPHN1, OPHN1 ${ }_{\mathrm{R} 409 \mathrm{~L}}$, or OPHN1 ${ }_{\triangle B A R}$. Cells were stimulated with 59 mM $\mathrm{K}^{+}$for 10 min and then incubated for 30 min at $4^{\circ} \mathrm{C}_{\text {in }}$ the presence of anti-DBH antibodies. (ells were then fixed (stimulated) or maintained for an additional 15 min period in Locke's solution (internalized) before fixation. Anti-DBH antibody detection was then performed as described above. $\boldsymbol{C}$, Representative confocal images. Scale bar, $5 \mu \mathrm{m}$. D, Analysis of DBH-positive vesicle endocytosis using a Euclidean distance map. Note that only 0 PHN1 ${ }_{\triangle B A R}$ affects DBH uptake. ${ }^{* *} p<0.01$ (Mann-Whitney test).

Using chromaffin cells from Ophn1 knock-out mice, we found that individual exocytotic events are affected by the absence of OPHN1. Amperometric analysis of catecholamine secretion revealed a decrease in both the amplitude and charge of pre-spike foots and spikes. This suggests a role for OPHN1 in fusion pore formation and enlargement. Conversely, the overexpression of OPHN1 increased pre-spike foot amplitude and charge, and the number of spikes, but without modifying the shape of the individual spikes. One possible explanation is that other components of the exocytotic fusion machinery might be rate limiting, preventing a further increase of the flux of catecholamines (spike amplitude). As well, OPHN1 expression does not modify the catecholamine content (spike charge) of each secretory granule, which is in line with our observations that granule size and catecholamine storage are apparently unchanged in Ophn1 knock-out mice. Using OPHN1 mutants, we found that OPHN1 requires its RhoGAP domain, but not its BAR domain, to play its function in exocytotic fusion, suggesting that a Rho protein is linked to the late stages of exocytosis and needs to be inactivated to somehow release the fusion machinery. Reduction of OPHN1 expression affects essentially the RhoA activation/inactivation cycle in secretagoguestimulated PC12 cells. Thus, RhoA seems to be a target for OPHN1 in the exocytotic pathway, an idea that receives support from previous reports showing that the expression of a constitutively active RhoA mutant inhibits exocytosis in chromaffin and PC12 cells (Gasman et al., 1998; Bader et al., 2004), and from observations made in neutrophils, indicating that the inactivation of RhoA is a requisite for exocytosis (Johnson et al., 2012). In this context, it is also worth mentioning that the cellular release of vaccinia virus requires the inactivation of RhoA together with cortical actin depolymerization (Arakawa et al., 2007).

How might RhoA be involved in fusion pore formation? In chromaffin cells, the initial fusion pore between secretory granules and plasma membranes has been proposed to be essentially of a lipid nature and controlled by physicochemical laws (Oleinick et al., 2013). However, it is clear that the formation of this initial fusion pore formation requires SNARE proteins (Kesavan et al., 2007; Bretou et al., 2008) and can be influenced by local substructures like the acto-myosin system (Doreian et al., 2008; Neco et al., 2008; Berberian et al., 2009). RhoA might interfere with SNARE functions through the RhoA/ROCK (Rho-kinase) pathway, which has been described to phosphorylate syntaxin1A and/or promote its associa- 
tion with negative regulators like tomosyn (Sakisaka et al., 2004; Gladycheva et al., 2007). RhoA/ROCK is also known to phosphorylate myosin light chain and stimulate acto-myosin contraction (Amano et al., 1996; Kimura et al., 1996), which might as well affect fusion pore properties (Doreian et al., 2008; Neco et al., 2008; Berberian et al., 2009). Finally, we cannot currently exclude that, in addition to RhoA, OPHN1 might fulfill its GAP activity towards an as yet unidentified Rho protein involved in the late fusion machinery.

In neuroendocrine cells, secretory granule exocytosis is tightly coupled to compensatory endocytosis, which allows specific granule membrane recapture and maintains cell homeostasis (Ceridono et al., 2011; Houy et al., 2013). We show here that compensatory endocytosis is severely impaired in chromaffin cells lacking OPHN1 expression. In line with this, OPHN1 has been implicated in synaptic vesicle recycling in hippocampal and cortical neurons (Khelfaoui et al., 2009; Nakano-Kobayashi et al., 2009; Powell et al., 2012), as well as in postsynaptic receptor endocytosis (Khelfaoui et al., 2009; Nadif Kasri et al., 2011). Additionally, we found that the expression of the OPHN1 mutant lacking the BAR domain severely inhibited $\mathrm{DBH}$ internalization, whereas the expression of the OPHN1 GAP-dead mutant had no effect. These data indicate that OPHN1 through its BAR domain plays an essential function in compensatory endocytosis of large dense core granule in chromaffin cells. BAR domains are known to constrain membranes into specific shapes and sense membrane curvature, and most likely act as scaffolds (Peter et al., 2004; Daumke et al., 2014). As such, BAR domain proteins appear as ideal candidates to regulate endocytotic processes. Experiments performed in neurons revealed that OPHN1 function in synaptic vesicle recycling requires the interaction with endophilin A1, another BAR domain-containing protein involved in endocytosis (Nakano-Kobayashi et al., 2009). Additionally, OPHN1 has been shown to interact with and recruit several other endocytic proteins containing a BAR domain such as amphiphysin and endophilin B2 (Khelfaoui et al., 2009). Whether BAR domain scaffolds are created to sense and/or to generate membrane curvature at the endocytic sites is currently unknown. Moreover, exactly how the OPHN1 BAR domain controls compensatory endocytosis in chromaffin cells and whether it requires additional protein interactions remain to be investigated. The importance of the OPHN1 BAR domain in synaptic vesicle recycling or postsynaptic receptor endocytosis has never been explored. This will be of particular interest because genetic mutations in the OPHN1 gene leading either to the deletion of the BAR domain or to a nonfunctional BAR domain with a 16 aa in-frame insertion have been detected recently in patients with intellectual disability (Pirozzi et al., 2011; Santos-Rebouças et al., 2014).

To conclude, we describe here for the first time a bifunctional protein, OPHN1, that is involved in both exocytosis and endocytosis in chromaffin cells. As a scaffold multidomain protein, OPHN1 has many assets to tightly coordinate large dense core granule exocytosis to compensatory endocytosis in neuroendocrine cells. Indeed, we found that OPHN1 is linked to the formation of the exocytotic fusion pore through its Rho-GAP domain and controls subsequent granule membrane retrieval through its BAR domain, thereby providing a structural checkpoint to spatially and temporally couple exocytosis and endocytosis in neuroendocrine cells. The next challenging question will be to ask whether OPHN1 might be able to shift the imbalance between exocytosis and endocytosis, and thereby hormone secretory ac- tivity in general, and to unravel the upstream regulatory signals. Additionally, from a more physiological point of view, it would be of primary interest to investigate whether, in addition to neuronal defects and associated cognitive disabilities, patients with mutations in the OPHN1 gene display neuroendocrine disorders.

\section{References}

Albillos A, Dernick G, Horstmann H, Almers W, Alvarez de Toledo G, Lindau M (1997) The exocytotic event in chromaffin cells revealed by patch amperometry. Nature 389:509-512. CrossRef Medline

Amano M, Ito M, Kimura K, Fukata Y, Chihara K, Nakano T, Matsuura Y, Kaibuchi K (1996) Phosphorylation and activation of myosin by rhoassociated kinase (rho-kinase). J Biol Chem 271:20246-20249. CrossRef Medline

Arakawa Y, Cordeiro JV, Schleich S, Newsome TP, Way M (2007) The release of vaccinia virus from infected cells requires RhoA-mDia modulation of cortical actin. Cell Host Microbe 1:227-240. CrossRef Medline

Bader MF, Doussau F, Chasserot-Golaz S, Vitale N, Gasman S (2004) Coupling actin and membrane dynamics during calcium-regulated exocytosis: a role for Rho and ARF GTPases. Biochim Biophys Acta 1742:37-49. CrossRef Medline

Berberian K, Torres AJ, Fang Q, Kisler K, Lindau M (2009) F-actin and myosin II accelerate catecholamine release from chromaffin granules. J Neurosci 29:863-870. CrossRef Medline

Billuart P, Bienvenu T, Ronce N, des Portes V, Vinet MC, Zemni R, Roest Crollius H, Carrié A, Fauchereau F, Cherry M, Briault S, Hamel B, Fryns JP, Beldjord C, Kahn A, Moraine C, Chelly J (1998) Oligophrenin-1 encodes a rhoGAP protein involved in X-linked mental retardation. Nature 392:923-926. CrossRef Medline

Bretou M, Anne C, Darchen F (2008) A fast mode of membrane fusion dependent on tight SNARE zippering. J Neurosci 28:8470-8476. CrossRef Medline

Bretou M, Jouannot O, Fanget I, Pierobon P, Larochette N, Gestraud P, Guillon M, Emiliani V, Gasman S, Desnos C, Lennon-Duménil AM, Darchen F (2014) Cdc42 controls the dilation of the exocytotic fusion pore by regulating membrane tension. Mol Biol Cell 25:3195-3209. CrossRef Medline

Bruns D, Jahn R (1995) Real-time measurement of transmitter release from single synaptic vesicles. Nature 377:62-65. CrossRef Medline

Ceridono M, Ory S, Momboisse F, Chasserot-Golaz S, Houy S, Calco V, Haeberlé AM, Demais V, Bailly Y, Bader MF, Gasman S (2011) Selective recapture of secretory granule components after full collapse exocytosis in neuroendocrine chromaffin cells. Traffic 12:72-88. CrossRef Medline

Chow RH, von Rüden L, Neher E (1992) Delay in vesicle fusion revealed by electrochemical monitoring of single secretory events in adrenal chromaffin cells. Nature 356:60-63. CrossRef Medline

Croisé P, Estay-Ahumada C, Gasman S, Ory S (2014) Rho GTPases, phosphoinositides, and actin: a tripartite framework for efficient vesicular trafficking. Small GTPases 5:e29469. CrossRef Medline

Daumke O, Roux A, Haucke V (2014) BAR domain scaffolds in dynaminmediated membrane fission. Cell 156:882-892. CrossRef Medline

de Curtis I, Meldolesi J (2012) Cell surface dynamics- how Rho GTPases orchestrate the interplay between the plasma membrane and the cortical cytoskeleton. J Cell Sci 125:4435-4444. CrossRef Medline

Doreian BW, Fulop TG, Smith CB (2008) Myosin II activation and actin reorganization regulate the mode of quantal exocytosis in mouse adrenal chromaffin cells. J Neurosci 28:4470-4478. CrossRef Medline

Fauchereau F, Herbrand U, Chafey P, Eberth A, Koulakoff A, Vinet MC, Ahmadian MR, Chelly J, Billuart P (2003) The RhoGAP activity of OPHN1, a new F-actin-binding protein, is negatively controlled by its amino-terminal domain. Mol Cell Neurosci 23:574-586. CrossRef Medline

Frantz C, Coppola T, Regazzi R (2002) Involvement of Rho GTPases and their effectors in the secretory process of PC12 cells. Exp Cell Res 273: 119-126. CrossRef Medline

Gasman S, Chasserot-Golaz S, Popoff MR, Aunis D, Bader MF (1997) Trimeric $\mathrm{G}$ proteins control exocytosis in chromaffin cells. Go regulates the peripheral actin network and catecholamine secretion by a mechanism involving the small GTP-binding protein Rho. J Biol Chem 272:2056420571. CrossRef Medline

Gasman S, Chasserot-Golaz S, Hubert P, Aunis D, Bader MF (1998) Identification of a potential effector pathway for the trimeric Go protein asso- 
ciated with secretory granules. Go stimulates a granule-bound phosphatidylinositol 4-kinase by activating RhoA in chromaffin cells. J Biol Chem 273:16913-16920. CrossRef Medline

Gasman S, Chasserot-Golaz S, Popoff MR, Aunis D, Bader MF (1999) Involvement of Rho GTPases in calcium-regulated exocytosis from adrenal chromaffin cells. J Cell Sci 112:4763-4771. Medline

Gasman S, Chasserot-Golaz S, Malacombe M, Way M, Bader MF (2004) Regulated exocytosis in neuroendocrine cells: a role for subplasmalemmal Cdc42/N-WASP-induced actin filaments. Mol Biol Cell 15:520-531. CrossRef Medline

Gladycheva SE, Lam AD, Liu J, D’Andrea-Merrins M, Yizhar O, Lentz SI, Ashery U, Ernst SA, Stuenkel EL (2007) Receptor-mediated regulation of tomosyn-syntaxin 1A interactions in bovine adrenal chromaffin cells. J Biol Chem 282:22887-22899. CrossRef Medline

Govek EE, Newey SE, Akerman CJ, Cross JR, Van der Veken L, Van Aelst L (2004) The X-linked mental retardation protein oligophrenin-1 is required for dendritic spine morphogenesis. Nat Neurosci 7:364-372. CrossRef Medline

Harada A, Furuta B, Takeuchi K, Itakura M, Takahashi M, Umeda M (2000) Nadrin, a novel neuron-specific GTPase-activating protein involved in regulated exocytosis. J Biol Chem 275:36885-36891. CrossRef Medline

Houy S, Croise P, Gubar O, Chasserot-Golaz S, Tryoen-Toth P, Bailly Y, Ory S, Bader MF, Gasman S (2013) Exocytosis and endocytosis in neuroendocrine cells: inseparable membranes! Front Endocrinol (Lausanne) 4:135. CrossRef Medline

Johnson JL, Monfregola J, Napolitano G, Kiosses WB, Catz SD (2012) Vesicular trafficking through cortical actin during exocytosis is regulated by the Rab27a effector JFC1/Slp1 and the RhoA-GTPase-activating protein Gem-interacting protein. Mol Biol Cell 23:1902-1916. CrossRef Medline

Kesavan J, Borisovska M, Bruns D (2007) v-SNARE actions during $\mathrm{Ca}(2+)$ triggered exocytosis. Cell 131:351-363. CrossRef Medline

Khelfaoui M, Denis C, van Galen E, de Bock F, Schmitt A, Houbron C, Morice E, Giros B, Ramakers G, Fagni L, Chelly J, Nosten-Bertrand M, Billuart P (2007) Loss of X-linked mental retardation gene oligophrenin1 in mice impairs spatial memory and leads to ventricular enlargement and dendritic spine immaturity. J Neurosci 27:9439-9450. CrossRef Medline

Khelfaoui M, Pavlowsky A, Powell AD, Valnegri P, Cheong KW, Blandin Y, Passafaro M, Jefferys JG, Chelly J, Billuart P (2009) Inhibition of RhoA pathway rescues the endocytosis defects in oligophrenin 1 mouse model of mental retardation. Hum Mol Genet 18:2575-2583. CrossRef Medline

Kimura K, Ito M, Amano M, Chihara K, Fukata Y, Nakafuku M, Yamamori B, Feng J, Nakano T, Okawa K, Iwamatsu A, Kaibuchi K (1996) Regulation of myosin phosphatase by Rho and Rho-associated kinase (Rho-kinase). Science 273:245-248. CrossRef Medline

Li Q, Ho CS, Marinescu V, Bhatti H, Bokoch GM, Ernst SA, Holz RW, Stuenkel EL (2003) Facilitation of $\mathrm{Ca}(2+)$-dependent exocytosis by Rac1-GTPase in bovine chromaffin cells. J Physiol 550:431-445. CrossRef Medline

Livak KJ, Schmittgen TD (2001) Analysis of relative gene expression data using real-time quantitative PCR and the 2 (-delta delta $\mathrm{C}(\mathrm{T})$ ) method. Methods 25:402-408. CrossRef Medline

Malacombe M, Bader MF, Gasman S (2006) Exocytosis in neuroendocrine cells: new tasks for actin. Biochim Biophys Acta 1763:1175-1183. CrossRef Medline

Momboisse F, Ory S, Calco V, Malacombe M, Bader MF, Gasman S (2009a) Calcium-regulated exocytosis in neuroendocrine cells: intersectin-1L stimulates actin polymerization and exocytosis by activating Cdc42. Ann N Y Acad Sci 1152:209-214. CrossRef Medline

Momboisse F, Lonchamp E, Calco V, Ceridono M, Vitale N, Bader MF, Gasman S (2009b) betaPIX-activated Racl stimulates the activation of phospholipase $\mathrm{D}$, which is associated with exocytosis in neuroendocrine cells. J Cell Sci 122:798-806. CrossRef Medline

Mosharov EV, Sulzer D (2005) Analysis of exocytotic events recorded by amperometry. Nat Methods 2:651-658. CrossRef Medline

Nadif Kasri N, Nakano-Kobayashi A, Malinow R, Li B, Van Aelst L (2009) The Rho-linked mental retardation protein oligophrenin-1 controls syn- apse maturation and plasticity by stabilizing AMPA receptors. Genes Dev 23:1289-1302. CrossRef Medline

Nadif Kasri N, Nakano-Kobayashi A, Van Aelst L (2011) Rapid synthesis of the X-linked mental retardation protein OPHN1 mediates mGluRdependent LTD through interaction with the endocytic machinery. Neuron 72:300-315. CrossRef Medline

Nakano-Kobayashi A, Kasri NN, Newey SE, Van Aelst L (2009) The Rholinked mental retardation protein OPHN1 controls synaptic vesicle endocytosis via endophilin A1. Curr Biol 19:1133-1139. CrossRef Medline

Nakano-Kobayashi A, Tai Y, Nadif Kasri N, Van Aelst L (2014) The $\mathrm{X}$-linked mental retardation protein OPHN1 interacts with Homer1b/c to control spine endocytic zone positioning and expression of synaptic potentiation. J Neurosci 34:8665-8671. CrossRef Medline

Neco P, Fernández-Peruchena C, Navas S, Gutiérrez LM, de Toledo GA, Alés E (2008) Myosin II contributes to fusion pore expansion during exocytosis. J Biol Chem 283:10949-10957. CrossRef Medline

Oleinick A, Lemaître F, Collignon MG, Svir I, Amatore C (2013) Vesicular release of neurotransmitters: converting amperometric measurements into size, dynamics and energetics of initial fusion pores. Faraday Discuss 164:33-55. CrossRef Medline

Ory S, Gasman S (2011) Rho GTPases and exocytosis: what are the molecular links? Semin Cell Dev Biol 22:27-32. CrossRef Medline

Ory S, Ceridono M, Momboisse F, Houy S, Chasserot-Golaz S, Heintz D, Calco V, Haeberlé AM, Espinoza FA, Sims PJ, Bailly Y, Bader MF, Gasman S (2013) Phospholipid scramblase-1-induced lipid reorganization regulates compensatory endocytosis in neuroendocrine cells. J Neurosci 33: 3545-3556. CrossRef Medline

Peter BJ, Kent HM, Mills IG, Vallis Y, Butler PJ, Evans PR, McMahon HT (2004) BAR domains as sensors of membrane curvature: the amphiphysin BAR structure. Science 303:495-499. CrossRef Medline

Pirozzi F, Di Raimo FR, Zanni G, Bertini E, Billuart P, Tartaglione T, Tabolacci E, Brancaccio A, Neri G, Chiurazzi P (2011) Insertion of 16 amino acids in the BAR domain of the oligophrenin 1 protein causes mental retardation and cerebellar hypoplasia in an Italian family. Hum Mutat 32:E2294-E2307. CrossRef Medline

Poëa-Guyon S, Ammar MR, Erard M, Amar M, Moreau AW, Fossier P, Gleize V, Vitale N, Morel N (2013) The V-ATPase membrane domain is a sensor of granular $\mathrm{pH}$ that controls the exocytotic machinery. J Cell Biol 203:283-298. CrossRef Medline

Powell AD, Gill KK, Saintot PP, Jiruska P, Chelly J, Billuart P, Jefferys JG (2012) Rapid reversal of impaired inhibitory and excitatory transmission but not spine dysgenesis in a mouse model of mental retardation. J Physiol 590:763-776. CrossRef Medline

Randhawa VK, Thong FS, Lim DY, Li D, Garg RR, Rudge R, Galli T, Rudich A, Klip A (2004) Insulin and hypertonicity recruit GLUT4 to the plasma membrane of muscle cells by using N-ethylmaleimidesensitive factor-dependent SNARE mechanisms but different v-SNAREs: role of TI-VAMP. Mol Biol Cell 15:5565-5573. CrossRef Medline

Sakisaka T, Baba T, Tanaka S, Izumi G, Yasumi M, Takai Y (2004) Regulation of SNAREs by tomosyn and ROCK: implication in extension and retraction of neurites. J Cell Biol 166:17-25. CrossRef Medline

Santos-Rebouças CB, Belet S, Guedes de Almeida L, Ribeiro MG, MedinaAcosta E, Bahia PR, Alves da Silva AF, Lima dos Santos F, Borges de Lacerda GC, Pimentel MM, Froyen G (2014) A novel in-frame deletion affecting the BAR domain of OPHN1 in a family with intellectual disability and hippocampal alterations. Eur J Hum Genet 22:644-651. CrossRef Medline

Vitale N, Gensse M, Chasserot-Golaz S, Aunis D, Bader MF (1996) Trimeric $\mathrm{G}$ proteins control regulated exocytosis in bovine chromaffin cells: sequential involvement of Go associated with secretory granules and Gi3 bound to the plasma membrane. Eur J Neurosci 8:1275-1285. CrossRef Medline

Wang Z, Thurmond DC (2010) Differential phosphorylation of RhoGDI mediates the distinct cycling of Cdc42 and Rac1 to regulate secondphase insulin secretion. J Biol Chem 285:6186-6197. CrossRef Medline 